\title{
Social Realistic Projections of Galsworthy's Strife
}

\author{
Md. Amir Hossain ${ }^{1}$ \\ ${ }^{1}$ Department of English, IBAIS University, Uttara, Dhaka, Bangladesh \\ Correspondence: Md. Amir Hossain, Senior Lecturer, Department of English, IBAIS University, Uttara, \\ Dhaka-1230, Bangladesh. E-mail: amir.ju09@yahoo.com or amir.hossain.16578@gmail.com
}

\begin{abstract}
In this article, I intend to focus on the dramatic theory of Galsworthy with a view to fostering the realistic and psychological conflicts and dilemma of early $20^{\text {th }}$ century powerful and domineering people in England. Here, this paper can be applied through the critical judgments of two eminent literary critics of Galsworthy for depicting the controversial attitudes of John Antony, the Chairman of the Trenartha Tin Plate Works, and David Roberts, the Strike leader of the workers as reflected in the play-text, Strife. It aims also to look at social realism through the psychological viewpoints of Galsworthy. In this way, the whole submission deals with the analytical projections of social reality, Galsworthy as a realistic dramatist, the impact of social realism in the play, Strife, and its significance as well.
\end{abstract}

Keywords: David Roberts, Galsworthy, John Antony, social realism, Strife

\section{Introduction}

As a pragmatic and social thinker and critic, Galsworthy established himself as one of the prominent and influential playwrights in the history of English literature. He wanted to shed new light on the dark aspects of his contemporary society so as to bring about a significant change in the outdated social structure of the day. In order to fulfill the craving of his spirit, he wanted to focus on the art of characterization within the ring fence of the dominant thoughts and concepts by causing social, economic, domestic, or personal problems: the disparity between the rich and the poor, the clash between the labour and the capital, social and legal injustice, domestic tyranny, the class conflict and unhappy marriage. He wanted to focus on the sensibility of awareness concerning the evils of the people through the burning social problems of his contemporary England. He had a profound humanitarian outlook of life, and he tried to the best of his ability to adopt a realistic attitude. His realistic plays are shaped and inspired by high intention and imagination. He dealt with social reality like a social reformer. His role as a reformer and philanthropist did not let him stay in the magic world of fancy or idealism. Galsworthy used his dramatic trick as regards the manipulation of his characters and the weaving of his plot—construction around the central social themes.

Galsworthy's Strife is a play concerning the clash between capital and labour, the waste of force involved in the caste-feeling of capital pitted against the caste-feeling of labour, the nemesis of extremism, the conflict between opposing wills, the lack of cohesion between leaders and the followers, the conflict of intransigent personalities, the inability of peace and prosperity, and fanaticism and inflexibility in an industrial society. It also focuses on the social conflicts of industrial life and retard production between John Antony, the Chairman of the Trenartha Tin Plate Works, and David Roberts, the Strike leader of the workers. Through this play, Galsworthy wanted to highlight the revolutionary passions of the common workers against their ruling class for their rights of early $20^{\text {th }}$ century England. Thus, this paper aims to look at social realism, Galsworthy as a realistic dramatist, and the influence of social realism in the play, Strife, and its significance as well.

\section{Social Realism}

Realism is based upon an idea of reflection human life. The term refers to a common attitude that rejects idealization, escapism, and excessive qualities of romance in term of identifying the problematic aspects of a man's life. According to modern criticism, realism is an indirect, or a reproduction of reality, but a system of conventions producing an illusion of a real world beyond any discourse in terms of selection, exclusion, and description. In literature, realism is the practice of fidelity to nature, or to the reality of life. The realist emphasis on detachment and objectivity became integral to the novel in the late $19^{\text {th }}$ century. The word has also been used to denote excessive minuteness of detail with trivial subjects. The $20^{\text {th }}$ century saw a line between realist and anti-realist literature by representing the realist issues on one aspect of the line and fantastic issues on the contrary. The prevalent critical climate makes the division between realism and imagination on the magical realism for producing a stunted narrative without any aesthetic art. This hierarchical division of social and 
imagination into the classification of real and unreal literature is very common for which any social realist discourse can be assumed by the context of the historical trends of literature review (Chapter 2: Social Realism, p. 79).

Social realism derives from Russian inspired concepts concerning literary function in the revolutionary socialist society. The social realist discourse is established by a faithful reality in the author's sensibility to draw a new light on the documentary fashion and the structure of social reality. According to Dictionary of Literary terms by Coles, Realism is literary a method of reflecting life since it is untouched by idealistic and romantic dictum. As a writing style, realism depends on the utilization of specific details to interpret life in the faithful and objective ways. Realism is accepted in terms of time and its necessity. Realism in literature is used to determining a variety of approach in which pure reflection of reality is the target. Each involves a contrast between human idea or fancy and an outer reality independentce of mind. Reality has a cognitive or normative authority over the mind. According to Galsworthy, "the word 'realist' characterizes that artist whose temperamental preoccupation is with revelation of the actual spirit of life, character and thought with a view to enlighten him and others". The contrast between social reality and socialist reality is between 'is' and 'should be'. Social realism is the depiction of social reality in literature (Chapter 2: Social Realism, pp. 80-81).

However, this submission is made to apply the practice of social realism with a view to focusing on the social reality of Galsworthy's play-text, Strife as well as his faithful images of his age.

\section{Galsworthy as a Realistic Playwright}

John Galsworthy's conception of drama is based on realism and a general sense of morality. He believed that drama is a meaningful art form, capable of stirring the mind and bringing awareness of noble principles in human life. It is a medium through which a dramatist can portray a life as he realizes it. He held firmly that the realistic depiction of contemporary life through the play would serve a useful purpose. It would make people realize their shortcomings, awaken in them a sense of guilt and prepare them to change the defective structure of society. With such a noble purpose in mind, Galsworthy took playwriting. He never thought that drama was merely an instrument of cheap entertainment. He wants to draw a spire of meaning. He intended to disturb the complacent people of his time and shake them from their slumber. He wanted to bring to light the evils in society so as to bring about a reasonable change in the outdated social structure of the day. As a social thinker, Galsworthy employs his play to serve the purpose and humanitarian in him appeals for benevolence, tolerance and understanding. His plays are wrought out pieces - significant scenes from everyday life from which the inherent moral of which he speaks, emerges. The fabric of every Galsworthy's play is woven around some definite idea and an ethical idea. In order to fulfill the craving of his spirit, he places his characters and themes within the ring fence of the powerful thoughts and imaginative viewpoints which cause social, economic, domestic, or personal problems such as the disparity between the rich and the poor, the clash between the labour and the capital, social and legal injustice, domestic tyranny, the class conflict and unhappy marriage. These ideas shape the very backbone of his psychology.

While Galsworthy was careful that each play should incarnate an idea, he took care that his plays should not be sermons deliberately written. His method of presenting an idea is quite different from that of Barnard Shaw. Both Galsworthy and Shaw regarded drama as a meaningful form and emphasized its serious purpose on life. But, Shaw used drama to propagate his ideas and expounded his theories. He created the world of his own ideas which corresponds to reality. Galsworthy, on the contrary, aimed at offering a fancy of real human life on the centre stage. He thrills the heart and mind, Shaw agitated the mind. Galsworthy was disgusted with the then current unreal, romantic type of drama. The organic human being was the centre of attraction for Galsworthy. The uneven social condition of his time and the tyrannies inflicted on the individuals under them were very disturbing. The poor had to suffer in consequence of economic disparity that prevailed the aristocrats ruthlessly exploited their inferiors, and the members of the weaker sections of society had to bow before the law that was interpreted for the benefit of the titled and money class, a constant fight raged between the common man and the worn out values of the gentry and the materialistic views of the newly rich class of the manufacturers, women had to live their life according to the will of their husbands and could not get protection from society or law when singled out from the herd, the relations between labour and capital were not cordial, life in the prisons was hell for the prisoners. Galsworthy thought it reasonable to arouse public opinion against an unhappy state of affairs in his plays. Thus, he resorted strictly to the presentation of real life upon the stage because he wished to revolt against the artificial, bastard form of drama. He wanted to bring a sense of awareness among people of the evils of their systems by presenting the burning social problems of his contemporary age.

Galsworthy's aim is to communicate emotions, not to solve problem. He only poses a problem as it occurs in 
ordinary, real life. He brings into his dramatic vision of the conflicts and the motives which lead to conflict. He expresses them and the social waste and violence associated with them realistically (Chapter IV: Social Realism in The Selected Plays of John Galsworthy, pp. 10-11). The realism of the naturalist is as follows:

...disinterested, objective, and impersonal as science itself. Its main objective is the representation of the real world. That is why it subordinates plot to character. Every element of drama - situation, dialogue, setting, gesture and acting - contributes to the total unified effect. In dialogue, the naturalist practices an exact fidelity to everyday speech. (Note 1)

In his writing, Galsworthy speaks of 'naturalistic technique' not as the ideal technique, but highly advantageous. Naturalistic art is like a steady lamp, and it is held up from time to time for which any objects will be beheld for a space and got rid of the mists of prejudice and partisanship. Galsworthy desires to reproduce the natural spectacle on the English stage with detachment. He criticizes society with cold objectivity. He presents the case with equal fairness. Galsworthy is pre-eminently a realist. He sheds a new light upon the revelation of the real inter-relating spirit of life, character and idea to enlighten human psychology. He is distinguished from that artist whom, he calls romantic - whose temperamental purpose is the invention of a tale or design to delight himself and others. Lynton Hudson rightly observed that the drama to Galsworthy was, as poetry was to Wordsworth, a means of preaching. Wordsworth saw sermons in stones and Shaw wanted the audience to go to the theatre as they went to the Church.

Galsworthy is, fundamentally, a modern realist. His plays mirror contemporary society. He had a profound humanitarian outlook of life, and he tried to the best of his ability to adopt a realistic attitude. He was slow to condemn individuals. He was not sentimental in his approach, and only rarely did he rely upon pathos for the effect of his scenes. He had an excellent sense of dramatic architecture, and although his emphasis was not on individuals, he had a power to give the realistic quality to the persons with whom he dealt. Galsworthy is a great realistic writer. His realism should not be confused with the photographic representation of life. His realistic plays are, poignantly, shaped and inspired by high intention and imagination. He dealt with social reality like a social reformer. The social problem was the raw stuff of realism, it means through which he made his communication, evaluation and expression, to a large extent his imagination is enlivened by constructive imagination. He gave impressive close ups of life at its most damnable, but he had the artist's love of design, his eye for detail, his plays deal with contrasts. His role as a reformer and philanthropist did not let him stay in the magic world of fancy or idealism. He was a great lover of truth and presented life around him as he truly saw it. Galsworthy is, relentlessly, realistic in almost all his plays. He visualized through his temperament, not as many people would prefer to see them. An incorruptible lover of truth, he attempts to shape all his plots and problems with the greatest impartiality, allowing both sides to air their opinions and throwing light on their ideas in possible ways. For him, the task lies in the unrolling of the problem, not in the solution. The unrolling of the problem should serve to make us think and reflect to awaken our interest in what is unknown to us in a wrong light (Chapter IV: Social Realism in The Selected Plays of John Galsworthy, pp. 3-8). Galsworthy himself comments that realism has no reference to technique for which naturalism serves far well. A realist is tied to the naturalistic process for which he can be poetic, idealistic, fantastic, and impressionistic but illusive which is so far as he is a naturalist he cannot be. (Note 2)

Galsworthy's realism emerges primarily in two ways: theme and characterization. He depicts real society in all its aspects. He wrote his plays with a definite purpose. His purpose was to expose the shortcomings and evils of the existing social institutions. This could not have been achieved unless he presented a realistic picture of social life and institutions. He possessed a remarkable power of objective detachment in his portrayal of society. Galsworthy's plays, realistically, focus on modern society and its problems. He, totally, eschewed the romantic element in his presentation of problems. Ideas, institutions, morality, class interests and social force form its main theme. Many of his plays are based on an inexorable incompatibility between the justice of society, and what is actually just. He also handles definite problems of marriage, of sex relationship, of labour disputes, of the administration, of the law, of solitary confinement, but for him the individual problem leads always to the general relations between individuals within the social organism. He suggested no practical reform, though reform appeared in his constant indication of existing wrongs. The source of evil for him laid in failure of imagination and sympathy. His character-portrayal is equally realistic. He draws his characters from his real experience of persons or situations around him. His characters are living human beings, whom we can meet in any day of our life. All his characters even the heroes are ordinary men possessed of common human weaknesses and frailties. Galsworthy is a realistic artist. He adds his own sympathetic view with a humanitarian zeal. To read his plays is to study all the prominent English social institutions of his day. To awaken a sense of injustice against social evils, Galsworthy uses his trick as regards the manipulation of his characters and the weaving of 
his plot-construction around the central social themes.

Galsworthy was a judge of facts, and he could look towards things dispassionately and as objectively as he could. Of course, he could not maintain ruthless objectivity as he was, obviously, sympathetic towards the afflicted and the poor. His sympathy for the sufferers did not mar his art. He was not a prejudiced or partial while presenting life's problem in his play, Strife because he knows that the realistic art is like a steady lamp. Even though Galsworthy established his reputation in the literary history of our time as a no negligible figure both in fiction and in drama, it had to be admitted somewhat regretfully for the matter of research-activity, which studies of his work to date have been few and far between. In the awareness of that not even much spade work has been done on the chosen author, thus the reasons made above, this study aims at closing a systematic study of social realism to be found in the considerable body of Galsworthy's drama, Strife (Kaye-Smith, 1916).

\section{Social Realism in the play, Strife}

John Galsworthy wrote the play, Strife in 1907. His dramatic art was absorbed into the general development of English realist theatre. Some harsh critics of today who become oblivious of Galsworthy's age speak of superfluous characters, lack of dramatic tension and sentimentalization of the situation arising out of the death of Mrs. Roberts, the wife of the strike-leader Mr. Roberts. Despite its negligible flaws, Strife was a great success in London and in New York and later on in Vienna in 1913. Its popularity is of lasting nature because it portrays the eternal battle between Capital and Labour, the employers and the employees. The rise to real power of the English Labour Mmovement early in the $20^{\text {th }}$ century provided a subject suited to Galsworthy's realistic method: Strife comes closest, among his plays to a work of lasting value. Through the careful dramatic opposition of ideas, characters, metaphors and structural elements, the play focuses on the tragedy of two fanatically iron-willed leaders who battle against each other at great cost to themselves and their followers. It is a beautiful indictment of the present structure of industrial society. It presents the strife between the capital and the labour, and advocates better understanding between these two great forces of our industrial life. The leader of the capitalists is Anthony and the leader of the labourers is Roberts. Galsworthy argues that the interest of industrial harmony both capitalists and the labourers should work in union and should not unnecessarily fight for their rights. There should be reconciliation between the two parties since unnecessary strikes and lock-outs hamper the progress of industrial life and retard production.

Galsworthy constructed the play so that its spire of meaning would arise from the dialectic of the opposing concepts represented by Anthony and Roberts. They refuse to compromise their principles by giving into the other side; their rigidity of purpose shows a kind of heroic intellectual vainglory, producing bitterness, suffering, waste and death. Galsworthy once more created "type" characters, but Anthony and Roberts are types as extremists, not as members of any social class such men may be found in any class of our time. He imposes structural balance on the action to achieve the resonant effect of contrast and parallelism of idea, character and situation. The confrontations of labour and the management in the first and the third acts balance each other, as do the separate meetings of directors and strikers in the second and the third acts, in which each side rejects its leader's plan for action and decides to accept instead the terms for compromise proposed by the union representative. Galsworthy handles his large cast of characters with a schematic balancing of psychological and social types. He also uses settings, properties and dramatic language appropriate to the theme of Strife; in several scenes, he contrasts the excesses of cold and heat, hunger and plenty, luxury and deprivation. Metaphoric language carries the idea that is Anthony and Roberts are like gods in their power over men, they are also like devils in the way they use power to cause sufferings for the sake of their principles.

The play, Strife, in an understated and better conclusion, neither celebrates nor condemns the opposing sides in the struggle of labour verses capital; instead it portrays the need for civility and compromise in human affairs. The plan opposed by the union representative at the beginning of the play is adopted; Anthony and Roberts have a moment of mutual recognition after their followers have rejected the inhumanity of blind, proud adherence to principle. The theme of hubris is, carefully and obviously, portrayed in Galsworthy's systematic balancing of scenes, characters and metaphors and in the working out of a metaphoric dialectic of opposed ideas. Strife, nevertheless, remains Galsworthy's best problem and a realistic play and the best realization of his theory of drama. For Galsworthy, the subject of the play, namely, the strife between capital and labour, was typical.

Strife is a drama of irreconcilable extremism. Written on the theme of Capital and Labour, it points out the stupidity of fighting to a finish. In the uncompromising state of affairs lies a tragic disaster. Galsworthy was the prophet of toleration. He believed that the sword perishes by the sword. The fatal thing in human personality is strong will minus self-control and balance. Such a will resembles Hubris which the Greeks regarded as the principal cause of tragedy. Violence is the prominent thematic strand of the play but, it is the result of dead 
hardness. The two powerful characters of the play-text namely John Anthony, the Chairman of the Trenartha Tin Plate Works, and David Roberts, the strike leader of the workers, have been responsible for immeasurable violence due to their rigid attitudes, because of their conflicts, the workers have been on the strike for six months. While the Company has reached the verge of disintegration, the workers have come to the brink of death for starvation. On both sides the obstinacy of the leaders presents a big contrast to the relenting spirit of the followers. Among the employers, it is the iron will and unyielding nature of John Anthony, and among the workers, it is the unbending will of Roberts that creates a serious deadlock. Ultimately, Anthony is voted down by his men, and Roberts is ignored by the strikers whom he was leading because they arrive at a settlement behind the scene. The crest-fallen, now widowed, Roberts is shocked at this unexpected turn of the events. The Directors of the company have made terms without the Chairman and the workers have called off the strike without obtaining the consent of their leader.

Galsworthy is impressed by the waste and the misery which the strike brings about. He wants to prove that men should be ruled by reason and his proof lies in depicting the futility of quarrelling over differences of the opinions which could have been settled by arbitration or compromise. After all, the contending parties settled the dispute exactly on the terms and conditions which had been drawn up before the five-month-old strike began. Galsworthy writes that the action of Strife occurs on February 7, between the hours of noon and six in the afternoon, near to the Trenartha Tin Plate Works, on the borders of England and Wales, where a strike has been in progress throughout the winter. It is a bitter cold winter. The five month old strike has also made bitter the mood of the Company Directors and the lives of the workers who have started starving. Hunger has afflicted the workers' wives and children. They are without coals, without cigars, without food and without funds. They feel the pinch of striking work and going without wages. The Company Directors are also in an unhappy state of affairs. They have lost nearly fifty thousand pounds. Their customers are looking towards other companies and are signing contracts with them, and all this is only due to the adamant attitude of the Companiy's Chairman, John Anthony, who believes in, "No Surrender." Two months earlier when Roberts, the strike-leader met the Board of Directors at London, Anthony told him that he was a foolish uneducated man unable to comprehend the wants of the men he was representing. But, in the meanwhile, the Directors of the Company have started relenting. That is why on February 7, they meet at the house of the Manager, Francis Underwood to discuss the circumstances with Mr. Simon Harness, a Trade Union Official, and the Men's Committee on the spot. Henry Tench, Secretary of the Company, hopes that the meeting will end in a compromise and a settlement will be found for the dispute among the Union, the workers and the Company Directors. However, when the meeting takes place, the Chairman infuriates the Board of Directors by his firm statement: "No Surrender" The Directors ventilate their protests that he wants to act reasonably when the men send Roberts up to the Board in December. They should humour him in place of the Chairman by dropping his eyes before Anthony's and they snap his head off. They get them in by a little tact. At Anthony's reply: "No Compromise!", Wilder recounts the ill effects of the continuous strike, prices are going up daily, dividend is not paid, the old contracts will have to be worked off at the current price level, the shares are below par, they will drop to a half by the time of the next dividend, the prosperity of the Company will wither away. The Directors tell the Chairman to give up his bedrock principles. Wanklin remarks that they are with him in theory, but they are not all made of cast-iron. Anthony retorts that it is better go to the devil than give in. The appearance of Harness at the meeting shifts the discussion from themselves to between the Directors and the Workers' supporters. Harness tells Anthony and other members of the Board that he is quite frank with them. They are forced to withhold their support from the people because some of their demands are in excess of current rates. Harness hopes to make them withdraw those demands on that day, and to take it straight from him, they will back them again. Then, he wants to see something fixed up before he goes back to night (Chapter IV: Social Realism in The Selected Plays of John Galsworthy, pp. 23-29). Anthony replies: "If the men will come in, we will do something for them. This is no spirit of compromise" (A.I, p. 13). Harness asks the members of the Board of Directors individually: "Is that your opinion too, sir-and yours-and yours?"(A.I, p. 13).The Directors do not answer. Harness resumes that it is a kind of high and mighty aristocratic tone he thinks that he would grow out of it seems to him that he was mistaken. Galsworthy makes it one of his points that society must give up its old stupidity to improve matters. Harness tells the Board that the workers do not want pity, they seek justice. A little later, the tense situation relaxes a bit and Roberts tells the Board that every man is going short. They cannot be so bad off than they have been those past weeks. He advises Anthony to prepare himself for the worst that can occur to his company. Accidentally, he remarks that he knows the way the cat is jumping.' Anthony loves a fight with the men. He has fought them down four times. But this time Roberts warns him that he is fighting the last fight he will ever fight. The deadlock becomes too intense for other members of the Board. Anthony is compelled to adjourn the meeting to 5 o' clock. In the interval that follows Anthony hears a persuasive word from his daughter Enid. She calls 
upon him to relent. She recounts the distress the people are in. she talks of her own maid, Annie, who married Roberts. She is in wretched condition. Since the strike takes place, she has not been having food. Anthony does not want to yield even at Enid's suggestion. He tells her provided that nobody stood between the Capitalist and the continual demands of Labour, the latter would squeeze the farmer's throat. Enid hears her father's say that her sentiments will go at first, her culture, and her comforts will be going all the time. Enid says that she does not believe in the barriers between classes. Then, Anthony shouts that Enid does not believe in the barriers between the classes. Finally, it is for the sake of his health that Enid advises her father not to press his principles any further. Wind fails in her mission. And, before the drama moves towards the next stage, Tench speaks to Anthony that he knows him hold very strong views respectfully, and it is always his habit to look things in the face. But, he does not think that the Directors like it as they see it.

The directors see the crux of the matter but not Anthony. Frost, Anthony's servant, makes one of the best comments on behalf of Galsworthy, when he says that the strike puts all that strain on him. In the second act of the play, the scene shifts to the kitchen of Roberts' cottage where a meager little fire burns. The ladies present belong to the families of workers. Mrs. Roberts is ill. She is a thin, weak and dark haired lady, who is about 35 years. The condition of other women is no better. Strike has also bitterly told upon their health. Mrs. Bulgin is a little pale, and pinched up woman. Madge Thomas is a good looking girl, who is 22 . This young girl is in love with George Rous, hence a little unmindful of the effects of worker's strike. As the act opens, Mrs. Yeo talks of scarcity of money and material. Mrs. Rous talks nostalgically of the year of 1879 when most women around her were not even born or were in their early childhood. She tells them how the company started and her father working on the acid got a poisoned leg. Representing the fatalistic nature of the workers, Mrs. Rous calls the misfortune of her father an act of Providence. She regrets that there were no Compensation Acts then. The conversation of women in Roberts' kitchen reveals the sufferings of the workers on account of the long strike. They are penniless and in the grip of starvation. It is in this grim situation that Enid comes. She requests Mrs. Roberts to persuade her husband to bring an end to the strike. Enid is, in fact, one of the mouthpieces of Galsworthy's Strike. She speaks a bit realistically about the capital. She also blames the workers for their poverty because they spend a lot in wine and betting. Mrs. Roberts listens all this, and she makes a startling statement that Roberts does not touch a drop of wine, and he does not bet with anybody in his life. It is also through Mrs. Roberts that we learn more about the cause of the labour. She represents her husband that Roberts comments that a working man's life is like a gamble from the time he is born to the time he dies. Roberts is a man of character, says his wife. He does not want to have a farthing from anybody, when the others are suffering. When Roberts returns to his cottage, Enid pleads with him for a compromise. She tells him to quit the strike for the sake of everybody and for his wife. Roberts says that she pleads for her father's sake and then, we learn the old truth about Anthony and Roberts from Enid. Acting on one's principles without the spirit of give and take is the cause of the whole problem. Anthony does not want to surrender, Roberts does not want to finish his game. One worker, Chapel says that the strike has gone beyond its proper limits. Roberts pleads for modification in their demands. The suffering workers are already in the mood of compromise, he has made an impression on them. He pleads for the suspension of the strike because its continuation is against the law of nature. The act ends on a tragic note. The wife of Roberts dies. She has a weak heart, no doubt, but the strike inflicted its blow on her frail health. The workers' reaction towards the strike is anti-Roberts. They believe that they had enough of it. There is a fight among them. In Act III, Anthony and Roberts continue to maintain their uncompromising attitude about the strike. Anthony is further let down by his own son, Edgar. It also reveals the generation gap. The new generation is more considerate to the working class. He sympathizes on the death of Mrs. Roberts and decides to resign his directorship. Anthony does not change even at the suggestion of his son. Apart from his kith and kin, Anthony has to face opposition from the members of the Board (Chapter IV: Social Realism in The Selected Plays of John Galsworthy, pp. 30-31).

\section{The Significance of the Play, Strife}

The play, Strife appeals on many levels of meaning. It is a play about the clash between capital and labour, the waste of force involved in the caste-feeling of capital pitted against the caste-feeling of labour, the nemesis of extremism, the conflict between opposing wills, the generation gap represented by Anthony and his children-Enid and Edgar, the lack of cohesion between the leaders and the followers, the conflict of intransigent personalities, the inability to change with the times and lead a life of peace and prosperity, and the logic that fanaticism and inflexibility alike over reach themselves in a society which ought to thrive on mutual understanding, especially in trade disputes. Anthony does not fight for himself but his class. He owes a duty to capital not only national but also international. His belief is that masters and servants are two different classes. They have different fates and different destinies. Their sensibilities, their ideologies, their attitudes are different. 
Masters and men cannot be equal. Where two men meet together, a good man will dominate. The interests of the two classes - the labour and the capital - are poles apart. They can never be the same. The whole truth is that men will never become masters.

Galsworthy points out the way of peace and prosperity in the midst of the class struggle.

Philosophically, the play has a universal idea. It is Galsworthy's own words, the perishing of the sword by the sword. The fatal thing is strong will minus self-control and balance. Galsworthy claims that he is an impartial observer in the clashes between his major characters. In Strife, Roberts and Anthony are allowed to present their cases with utter objectivity, yet we find that Galsworthy's sympathy is with Roberts (Chapter IV: Social Realism in The Selected Plays of John Galsworthy, pp. 32-35). As A. C. Wards (1994) commented:

The scales are held dispassionately by the dramatist, and the audience feels only the desperate futility of the tragic pride and prejudice on both sides. But then by his choice of incident at the climax of the play, Galsworthy destroys in a moment the illusion of impartiality. The death of Mrs. Roberts is not an appeal to human instincts of harmony and justice; it is an appeal to humanitarian sentiment which, fundamentally, has no bearing upon the real problem of Strife. (Note 3)

The play has no heroes in the traditional sense of the word. Neither Roberts nor Anthony is a heroic figure. They are the two best men, both of them are broken. A. Nicoll (1994) rightly argued,

Galsworthy makes neither Anthony nor Roberts a man who governs events. Both have iron will and are determined to fight to the bitter end, but they are not drawn in individualistic heroic terms. The one takes his strength from what may be called the capitalist faith, the other from the faith of the rebels. Fundamentally, each is incapable of acting otherwise than he does. Capital makes Anthony what he is. He can change even if the times have changed. Labour has made Roberts the person he is. He believes that the god of capital and the god of labour are two different powers. (Note 4)

In Strife, Galsworthy makes the invisible social structure the hero and the characters act mere puppets. They have very little independent existence. Even when they are individualized; they are intensely typical. They represent common human lapses and weaknesses. All of them show their weakest spots in a time of struggle. All of them are selfish human beings. They suffer from internal schisms and rivalries. Anthony and Roberts are left alone. Their followers drift away from them and end the strife on their own terms. Hence, it is not the personal hero that governs the events of the play. It is the social structure and that is where the fun comes in Galsworthy's play, Strife which strongly stresses this type of injustice. One fully realizes how utterly hopeless the life of workers is. They simply cannot raise their hands and walk like free and equal species of mankind.

\section{Conclusion}

To conclude, we can assume that Galsworthy's play, Strife is based on the social conflicts of industrial life and retard production between John Antony, the Chairman of the Trenartha Tin Plate Works, and David Roberts, the Strike leader of the workers through whom Galsworthy wants to show the adamant attitudes and psychological conflicts of his contemporary people. Through this text, Galsworthy wants to draw a new light on the revolutionary passions of the common workers against their ruling class for their rights as well as privileges of the early $20^{\text {th }}$ century England. He also intends to unveil the mysterious truth of his social reality. Actually, this paper is made to highlight social realism, Galsworthy as a realistic dramatist, and the impact of social realism in the play, Strife, and its significance as well.

\section{References}

$\begin{array}{lllll}\text { Chapter 2: } & \text { Social } & \text { Realism-Shodhganga. } & \text { Retrieved }\end{array}$ shodhganga.inflibnet.ac.in/bitstream/10603/709/6/06_chapter\%202.pdf

Chapter IV: Social Realism in the Selected Plays of John Galsworthy. Retrieved from Shodhganga.inflibnet.ac.in/bitstream/10603/10017/9/09_chapter4.pdf

Coats, R. H. (2002). A History of English Literature. Bareilly: Prakash Book Depott.

Galsworthy, J. (1911). Strife. London: Gerald Duckworth \& Co. Ltd.

Galsworthy, J. (1995). Some Platitudes of Drama. Delhi: Penguin Books Ltd.

Kaye-Smith, S. (1916). John Galsworthy. The Playwright. Delhi: Mcmillan India Ltd.

Nicoll, A. (1988). British Drama (p.136). Delhi: Doaba House.

Nicoll, A. (1994). World Drama (p. 293). London: George G. Harrap 7 Co. Ltd. 
Phelps, L. W. (1997). World Drama. New Delhi.

Skemp, A. R. (1913). The Plays of Mr. John Galsworthy. Mumbai: Penguin Books Ltd.

Ward, C. A. (1994). Galsworhty's Theory of Drama. Oxford: Oxford University Press.

Wimsatt, K., William, Jr, \& Brooks, C. (1974). Literary Criticism-A Short History. New Delhi: Oxford \& IBH Publishing Company.

\section{Notes}

Note 1. Galsworthy, John (1995). Some Platitudes of Drama.

Note 2. Coats, R. H. (2002). A History of English Literature.

Note 3. C. Ward, A. (1994). Galsworthy's Theory of Drama.

Note 4. Nicoll, Allardyce (1988). British Drama, p.136.

\section{Copyrights}

Copyright for this article is retained by the author(s), with first publication rights granted to the journal.

This is an open-access article distributed under the terms and conditions of the Creative Commons Attribution license (http://creativecommons.org/licenses/by/3.0/). 